\title{
МІЖНАРОДНЕ БЕЗПЕКОВЕ СЕРЕДОВИЩЕ: ВПЛИВ НА ФОРМУВАННЯ ПОЛІТИКИ ПРОФЕСІЙНОЇ ВІЙСЬКОВОЇ ОСВІТИ В УКРАЇНІ
}

У статті проаналізовано стислий стан міжнародного безпекового середовища на глобальному, регіональному рівні та внутрішньо-політична обстановка в краӥні, наведено окремі нові форми і способи сучасної збройної боротьби. Окреслені окремі питання щзодо формування політики професійної військової освіти через призму аналізу безпекового середовища та змін, щзо відбулися у війнах сучасності.

Ключові слова: безпекове середовище, політика професійної військової освіти, збройна боротьба, військовий конфлікт, сили оборони, воєнна підготовка

Постановка проблеми. Реалії життя вносять об’єктивні корективи чи обмеження у практичні кроки, оскільки зміна міжнародного безпекового середовища та внутрішньополітичних умов життя певною мірою впливають на обороноздатність держави та підготовку сил оборони до виконання покладених завдань із захисту країни. Виходячи із зазначеного, бажано дотримуватися розумного балансу між збереженням послідовності існуючого потенціалу та розвитку країни і корегуванням основ зовнішньої і внутрішньої політики, виважено підходу до реформування сектору безпеки і оборони. Стосовно реформи сфери безпеки і оборони слід уважно підходити до ролі внутрішніх $\mathrm{i}$ зовнішніх факторів об'єктивного та суб'єктивного характеру обстановки, що швидко змінюється та ускладняється.

Зовнішня політика та політика безпеки України 2014-2019 років значною мірою фокусувалась на проблемах, пов’язаних 3 протидією «гібридній» агресії, що має комплексний характер та несе загрози зовнішній та внутрішній безпеці України. Фактор збройного конфлікту справляв різноплановий вплив як на реформування сектору безпеки і оборони, так і на реалізацію намірів докорінної зміни професійної військової підготовки та освіти [1, с. 4-5].

Актуальність дослідження полягає в тому, що на сьогодні підхід до створення нової моделі політики професійної військової освіти вкрай назріло та потребує чіткої іiі систематизації враховуючи те, що головним воєнним ресурсом є населення України. Тільки висококваліфіковані та мотивовані люди можуть перетворити виділенні фінанси та системи озброєння у воєнні можливості, що необхідні для підтримання на певному рівні безпеки держави.

Аналіз досліджень і публікацій. В контексті реалізації курсу України до вступу в НАТО проводяться заходи щодо реформування системи військової 
освіти держави. Актуальність дослідження зумовлена перед за все недостатнім теоретичним визначенням змісту політики професійної військової освіти, наповненням, так i зростанням iі практичного значення у ситуації реформування сектору безпеки i оборони. Актуалізують тему дослідження формування політики військової освіти перед за все міжнародне становище, геополітичні виклики, міжнародний тероризм, гібридні та інформаційні війни. Сучасною концептуалізацією досліджень освіти та формування військової науки займались багато відомих науковців А. М. Зельницький, Ю. I. Приходько, В.М. Телелима $[2,3]$ та ін. Різні аспекти професійної підготовки і формування особистості військовослужбовця здійснено у працях військових науковців І. В. Дятлова, Д.В. Вітера, О.О. Мітягіна та ін. [4].

Мета статті полягає в підходах формування політики професійної військової освіти через аналіз міжнародного безпекового середовища та нових форм і способів ведення бойових дій, розглядається один з можливих підходів до оцінки зовнішньої та внутрішньої обстановки на сучасні підходи до підготовки майбутніх військовослужбовців.

Виклад основного матеріалу. На формування політики професійної військової освіти держави завжди впливав стан міжнародної (глобальної), регіональної та внутрішньої безпеки, а глибинний, науковий його аналіз для вироблення підходів до готовності країни до захисту свого суверенітету, територіальної цілісності та підготовки власних Збройних Сил та інших військових формувань до ведення бойових дій в сучасних умовах.

У сучасному світі геополітичні конфігурації швидко змінюються, посилюється суперництво глобальних і регіональних сил за перерозподіл сфер впливу та ринків збуту, особливо на пострадянському просторіпісля розпаду СРСР. Нові незалежні держави, що зазнають складних суспільно-політичних реформ, через політичну та стратегічну невизначеність стають об'єктами тиску - політичного, економічного, військового, інформаційного тощо. Унаслідок цього в них формується зона підвищеного ризику, обумовлена дією новітніх загроз, притаманних міжнародному без пековому середовищу.

На сьогодні Україна виходить 3 того, що однією 3 найважливіших гарантій їі суверенітету та сталого розвитку і підтримання системи колективної безпеки в європейському та трансатлантичному просторі $\epsilon$ розвинена кооперація в політичній, економічній, дипломатичній, гуманітарній, інформаційній та військовій сферах 3 країнами ЄС та Північноатлантичного альянсу. Підгрунтя такого співробітництва створюють процеси глобалізації економічних відносин, а також посилення тенденцій взаємовпливу, необхідності узгодження позицій усіх зацікавлених сторін з питань можливого застосування військової сили у ситуаціях, пов'язаних із забезпеченням тривалого миру в громадянських, міжетнічних, міжконфесійних та інших конфліктних ситуаціях.

Світ за останні десятиріччя після закінчення Другої світової війни не став спокійніше, у різних його кутках виникають війни чи збройні конфлікти (3 другій половині XX та початок XXI століть сталося понад 300 локальних війн i збройних конфліктів), в яких застосовується стрілецька зброя, бойова техніка та 
високоточна i високотехнологічна зброя. Наукова-технічна революція із перших кроків поставила перед людством питання про сферу використання іiі результатів, якою стала переважно військова сфера.

На сьогодні у світі продовжують тривати локальні збройні конфлікти в яких використовуються та випробуються новітні зразки озброєння, тактика дій збройних формувань, приватних військових компаній, Сил спеціальних операцій та вивчаються наслідки нових способів і методів збройної боротьби. Деякі локальні збройні конфлікти на сучасному етапі мають тривалість від 3 до 72 років (Індія у провінціях Джамму і Кашмір; Палестина та Ізраїль; Курдистан з Туреччиною, Іраком та Сирією; Афганістан; Сомалі; Чечня; Косово; Хорватія; Нагорний Карабах; Абхазія, Південна Осетія, Придністров'я та Донбас тощо) [5].

У всіх локальних війнах та збройних конфліктах застосовувалися новітні технології у військовій сфері. Так, у другий половині XX століття після Другий світової війни під час виникнення локальних збройних конфліктів частка високоточної зброї та крилатих ракет, нових зразків бойової техніки складала близько 13\%, на сьогодні застосування новітніх технологій перевищує понад $68 \% 3$ всіх залучених видів озброєння та бойової техніки. Наприкінці XX 3 початком XXI століття з'явилися нові види війн - як санкційні (економічні, політичні, дипломатичні, спортивні, культурні), гібридні, інформаційні, кібер $[6$, c.9].

Сьогодні світ вступив в нову воєнну еру - еру війн новітніх технологій, створення принципово нової цивілізації - інформаційної. Масова комп'ютеризація, впровадження та розвиток інформаційних технологій призвели до ривку в освіті, економіки, науки, соціальному житті та воєнній справі. Інформація перетворилась в глобальний, невиснажений ресурс людства, використання якого дозволяє значно збільшити управління всіма сферами життя. Відтак витікає об’єктивна трудність прогнозування збройної боротьби, так як основні сфери життя знаходяться на переломному етапі - перехід від індустріальної до інформаційної цивілізації. Такі стрімкі зміни у світі впливають на формування політики професійної військової освіті та підготовку майбутніх офіцерів.

Отже, підчас формування політики професійної військової освіти потрібно перш за все враховувати глобальні, регіональні зміни, що відбуваються в світі, вивчати та аналізувати загрози і ризики національній безпеці держави, брати на озброєння зміни в стратегії та тактики сучасної збройної боротьби й впроваджувати нові стандарти, форми і методи навчання майбутніх захисників України.

Таким чином політика професійної військової освіти - це стратегічний документ в якому відображаються інституційні та організаційні зміни у сучасних підходах до воєнної науки та надаються заходи 3 підвищення професійної підготовки військовослужбовців, враховуючи стан міжнародної безпеки й нових форм і способів ведення збройної боротьби (війни).

На нашу думку, політика професійної військової освіти повинна включати в себе таки основні розділи та враховувати: 
міжнародне безпекове середовище (глобальний і регіональний ії стан); внутрішній стан розвитку держави та ії спроможності;

вивчення причин та умов виникнення локальних війн та збройних конфліктів, форм, способів і методів застосування воєнної сили чи невійськових засобів пливу для вирішення конфліктів;

аналіз науково-технічного розвитку та його вплив на сучасний розвиток країни та її збройних сил;

стан готовності сектору безпеки і оборони до виконання покладених на нього завдань у різних умовах обстановки, що складається;

вироблення оптимальних сценаріїв розвитку ситуації для країни й шляхи вирішення та способів захисту суверенітету й територіальної цілісності (Рис. 1).

В умовах виникнення нових загроз національній безпеці України, зростання воєнної мощі сусідніх 3 країною держав та наявності внутрішніх проблем, Україні необхідна сучасна високопрофесійна та інноваційна армія, де до професіоналізму, технічного кругозору i компетентності військових пред’являються вимоги принципово іншого рівня.

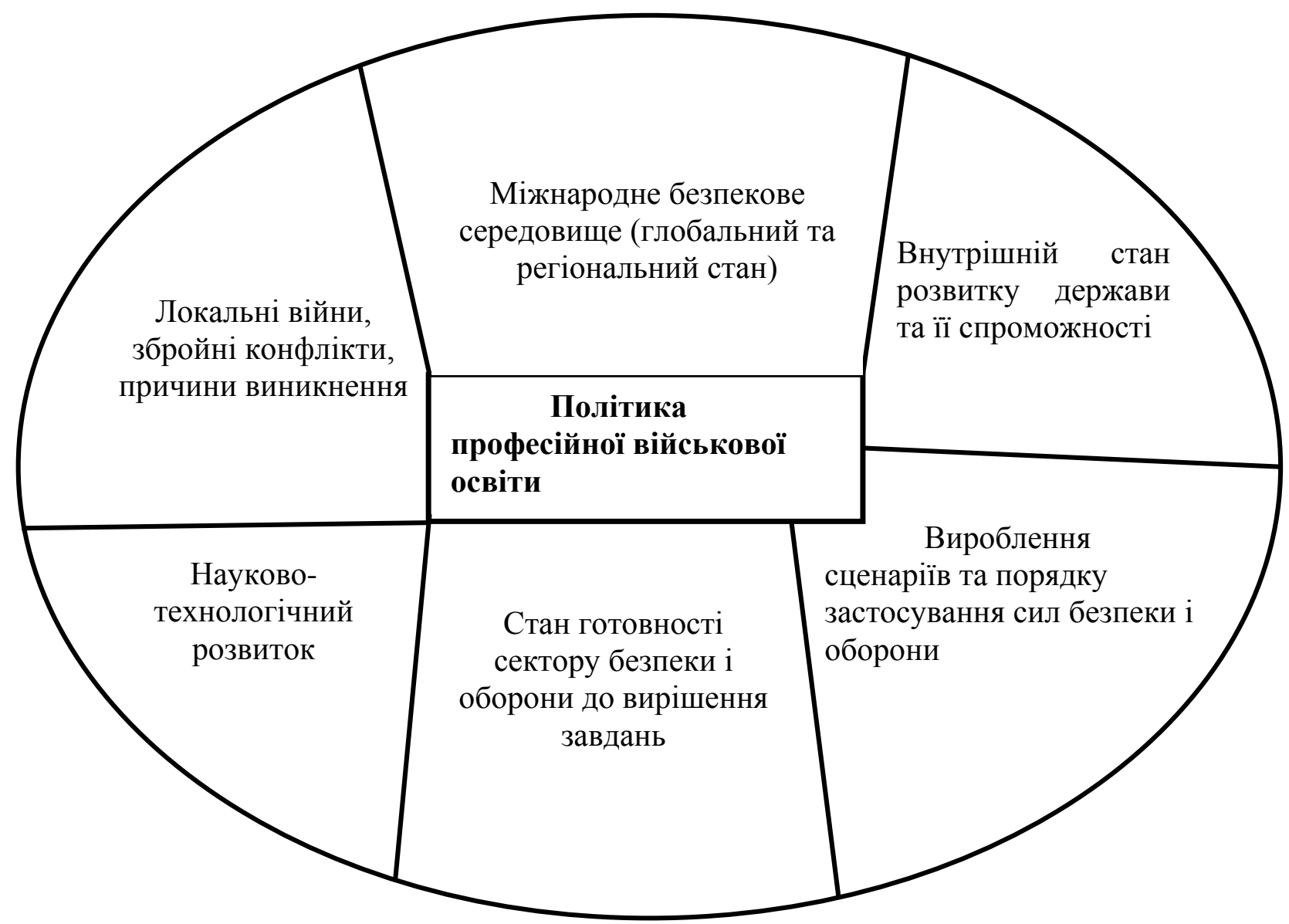

Рис.1 Основні складові формування політики професійної військової освіти

Невід'ємною частиною в системі професійної військової освіти єформування у військовослужбовців широкого кругозору 3 питань міжнародних відношень та політики безпеки, що дозволяє вести офіцерам всіх 
ланок професійну діяльність у визначеній сфері та виконувати завдання за спеціальністю. Одними з основних компетенцій з підготовки сучасних офіцерів $\epsilon$ вміння розбиратися у питаннях міжнародної обстановки, прогнозувати наслідки подій, що відбуваються навколо держави та вжиття певних заходів для підвищення боєздатності своїх підрозділів, частин та об'єднань.

Отже, по-перше - на глобальному рівні міжнародне безпекове середовище залишиться під впливом боротьби світових країн-лідерів за ринки збуту, економічного, політичного та ідеологічного протистояння (США, НАТО, ЄC, Китаї, Росія, ОДКБ, Митного Союзу). 3 точки зору національних інтересів України потребує:продовження країни політичного курсу щодо надання ій статусу основного союзника США та отримання членства у НАТО і розвиток військово-технічного співробітництва 3 його членами; збереження/посилення санкційного тиску на Російську Федерацію, зокрема блокування російських проєктів «Північний потік-2» і «Турецький потік»; консолідація міжнародних зусиль $з$ де-окупації тимчасово окупованих територій за прямої участі або за підтримки США та країн Свропейського Союзу (Кримська платформа, Нормандський формат, Вишеградська четвірка тощо). Тому збереження актуального конфліктного потенціалу без значної ескалації бойових дій та підтримання наявного рівня взаємодії у відносинах з США, КНР, РФ та СС буде залишатися.

Роль і ступінь впливу США на формування міжнародного безпекового порядку денного буде визначатися: внутрішньополітичною ситуацією в країні; динамікою відносин з РФ і КНР на глобальному рівні;діалогом з Україною у контексті подальшого тривалого збройного конфлікту на сході країни та наявності тимчасово окупованих територій; співпрацею 3 регіональними партнерами по НАТО (Туреччиною, Румунією, Польщею, Угорщиною та країнами Балтії) 3 метою стримування російської військової присутності у басейні Балтійського та Чорного морів, регіоні центральної та східної Свропи, Східному Середземномор'ї.

Північноатлантичний союз продовжить трансформуватися та шукати шляхи зміцнення свого потенціалу на тлі протиріч, що виникли всередині самого Альянсу. Так, члени блоку наголошуючи на важливості захисту кожного члена НАТО, маючи на увазі російську загрозу, водночас зіштовхуються 3 проблеми всередині блоку, що назрівають між Грецією та Туреччиною, США і Туреччиною через покупкою останньої у Росії протиповітряних комплексів С400 «Тріумф» та США і Німеччиною через газо-нафтопровід «Північний поток2». Не вирішено питання у середині блоку із збільшення витрат європейських країн - членів НАТО на оборону,на що вказує керівництво США, яким набридло нести більшість витрат для оборони Свропи.

Роль Китаю у питаннях міжнародної безпеки швидко зростає як важливий фактор економічної та інформаційної безпеки.Стратегічні ініціативи Китаю, зокрема проєкти BRI (Ініціатива Поясу і Шляху), «17+1», програми MIC 2025 («Зроблено у Китаї 2025»), інвестиції у програми розвитку високих технологій (на кшталт 5G компанії HUAWEI та штучного інтелекту) спрямовані на забезпечення китайського лідерства у сфері високих технологій і конкурентних 
переваг у глобальному протистоянні 3 США. Враховуючи сучасний економічний розвиток України стратегічна роль Китаю може мати вкрайнегативні наслідки для нашої країни, а саме: «кабальні» боргові зобов'язання, що загрожують національній безпеці; перехід стратегічно важливих об'єктів, портів і критично важливої інфраструктури країни до рук китайських інвесторів (як це було з концерном «Мотор Січ»); стимулювання недоброчесної конкуренції та розвитку «тіньової» економіки тощо). Водночас у військовій сфері Китаї поступається таким лідерам, як США і Росія, але намагається знайти шляхи для отримання сучасних технологій у сферах будівництва літаків, високоточної зброї та космосу.

Вплив пандемії COVID-19 на міжнародну безпеку слід розглядати крізь призму декількох факторів, а саме: кризи глобальної інфраструктури у сфері охорони здоров'я та неефективності національних медичних систем;економічної кризи;загострення глобального протистояння між США і КНР у сферах економіки, науки і технологій; продовження окремими країнами світу здійснювати розроблення біологічної та хімічної зброї.

По-друге, на регіональному рівні європейська архітектура безпеки зберігає поділ континенту на дві частини: НАТО/ЄС з одного боку та Російська Федерація з новоствореними структурами (ОДКБ, ЄврАзЕС, Митний союз тощо) - 3 іншого, між якими існує так звана «сіра зона» у вигляді низки пострадянських країн (Білорусь, Молдова), до яких входить і України. Отже, наша країни за цих умов постійно $є$ під зростаючим тиском різноспрямованих центрів впливу.

Можливості держави щодо протидії наслідкам такої ситуації довгий час стримувалися невизначеністю їі зовнішньополітичного курсу під час вирішення питань регіональної безпеки. Водночас характер новітніх воєнних загроз виключає можливість самостійного протистояння їм з боку окремих держав Свропейського простору.

Україна не є членом СС та НАТО, а тому не може брати повноцінної участі у формуванні механізмів європейської колективної безпеки. Не маючи власної потужної та ефективної системи безпеки й оборони, наша країна фактично опинилася сам на сам перед загрозою втрати територіальної цілісності. Як свідчать останні події, відносини партнерства з НАТО, так само як відносини сусідства з СС, принципово не вирішують проблеми ефективного протистояння новітнім загрозам, західні партнери лише на словах підтримують територіальну цілісність України (виконання Будапештського пакту 1994 року) [7, c.25-26].

Вплив Європейського Союзу на регіональну безпеку має виключно «м'які» санкціонні інструменти зовнішньої політики. Водночас посилення націоналістичних настроїв у багатьох європейських країн вносить все більший розкол всередині $€ \mathrm{C}$, поглиблюється криза у трансатлантичних відносинах, a усунення Франції від участі у врегулюванні Нагірно-Карабаського конфлікту на користь РФ i Туреччининегативно вплинуло на роль $Є С$ у питаннях регіональної безпеки. На сьогодні основнийвплив $Є С$ на регіональну безпеку $\epsilon$ 
механізм Східного партнерства, який, наразі потребує вироблення нових поглядів і підходів на тлі подій у Білорусі та Вірменії.

Ключовим чинником у регіональній безпецізалишається фактор Російської Федерації, який буде впливати на формат прийнятних для України моделей співіснування та будівництва взаємовідношень 3 іншими країнами. Вплив Росії на внутрішню і зовнішню політику країн регіону буде визначальним у формуванні безпекового середовища. При цьому слід враховувати наступне, що посилення Росії, iii військового, економічного, політичного, інформаційноготиску матиме негативні наслідки для регіональної безпеки, так саме погіршення ii внутрішньополітичної ситуації, радикалізація настроїв населення може створити нові загрози нестабільності у регіоні та призвести до виникнення нових осередків міжнаціональних та міжрелігійних конфліктів на державному кордоні України.

За оцінкою Об’єднаного управління розвідки і безпеки Міжнародного секретаріату НАТО, реакція Росії на події, що відбувалися на пострадянському простору, незважаючи на високій рівень регіональної нестабільності, була не до кінця дієвою. Вона утрималась від прямої підтримки своїх пострадянських сателітів. Водночас основні зусилля Росії зосереджувалися на недопущенні втручання Заходу у ситуацію в Білорусії, Молдові та на Південному Кавказі. Прогнозується подальше приховане втручання Російської Федерації у

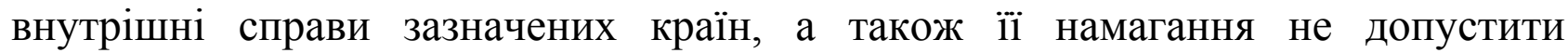
контролю на пострадянському просторі [8].

Орієнтовно на початку 2022 року з нової редакції Конституції Білорусі буде вилучено положення про нейтралітет країни та запропоновано закріпити статус Росії як стратегічного союзника у політичній, економічній і військовій сферах. У разі таких змін, передбачається перегляд концепції зовнішньої політики і оборони Білорусі з точки зору посилення союзницьких відносин 3 Російською Федерацією.

3 лютого 2021 року збільшується кількість спільних із збройними силами Росії та Білорусі заходів оперативної та бойової підготовки, а також забезпечення координації дій під час перекидання військ територіями обох країн (передусім залізничним транспортом) [8].

Через загострення внутрішніх протиріч в Україні, а саме на тлі мовного питання спеціальні служби Румунії та Угорщини здійснюють розробку керівництву країн пропозицій щодо можливих заходів політичного тиску на керівництво України. Пропозиції спрямовані на створення передумов для порушення на рівні міжнародних/регіональних організацій питання «належного забезпечення прав і свобод нацменшин в Україні» та формування пулу західних країн для «міжнародного осуду дій української влади» через «призму нацменшин».

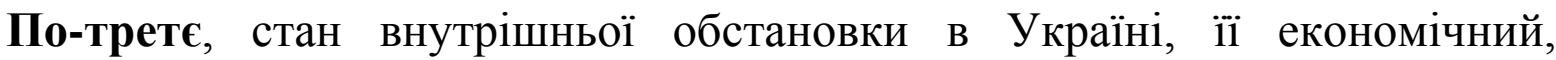
політичний, соціальний та ідеологічний розвиток та спроможність протидіяти воєнним загрозам.

Традиційно Україна в умовах геополітичного тиску з боку ключових міжнародних гравців будувала власну безпекову політику здебільшого в режимі 
реагування на виклики, що не залишало простору для реалізації масштабних стратегічних планів. Після підписання Угоди про асоціацію з Європейським Союзом Україна отримала можливість поступового переходу до політики, спрямованої на створення нової системи національної безпеки, яка відповідатиме масштабам існуючих загроз та направлена на інтеграцію у систему міжнародної та регіональної безпеки.

Продовження збройного конфлікту на сході країни(окремих районах Донецької та Луганської областей), відторгнення частини території України (Автономної Республіки Крим, міста Севастополь), підриває політичну, економічну i соціальну стабільність у країні; призводить до численних людських жертв, масштабних порушень прав i свобод людини; завдає величезних матеріальних збитків громадянам України, суб'єктам господарювання, суспільству в цілому. Порушення територіальної цілісності України посилює інші загрози їі суверенітету i створює перешкоди для повноцінного функціонування держави в межах міжнародно-визнаних державних кордонах.

Нарощування військових угруповань Російської Федерації поблизу державного кордону дестабілізує суспільно-політичну й соціально-економічну ситуацію в Україні та посилює загрозу розширення масштабів воєнного вторгнення, а військова допомога сепаратистам створюють реальну загрозу ескалації збройного конфлікту та вкрай ускладнюють його врегулювання переговорними засобами [9].

Зовнішні гарантії безпеки України за Статутом ООН, Гельсінським заключним актом 1975 року, Будапештським меморандумом 1994 року виявилися недієвими, а провідні міжнародні організації з безпеки не знайшли ефективнихзаходівстримування агресивності Росії. Це продемонструвало слабкість міжнародної системи безпеки, неефективність міжнародних інституцій $(\mathrm{OOH}$, ОБСС, ПАРЕ), що не дозволяє Україні розраховувати на існуючі в їх рамках міжнародно-правові механізми для захисту національних інтересів.

Унаслідок поширення корупції діяльність державних органів виявилася фактично підпорядкованою корпоративним та особистим інтересам, а подеколи й інтересам інших держав. Численні хаотичні трансформації дезорганізовували роботу державних органів, практика призначень за принципами політичної лояльності й корупційної «доцільності» призвела до критичної депрофесіоналізації державної служби.

Низько-технологічна, олігархічна модель економічного розвитку України, деформована економічна політика, фактично спрямована на привласнення суспільних ресурсів, а надмірна залежність національної економіки від кон'юнктури зовнішнього ринку в сукупності створили передумови для глибокої економічної кризи.

Цілеспрямована інформаційна війна, яка ведеться проти України усіма засобами пропаганди, створює життєво небезпечну загрозу національним інтересам України як на іiі території, так і за кордоном. Гострою залишається загроза застосування проти об’єктів критичної інформаційної інфраструктури 
системних кібератак та проведення кібертерактів, що може призвести до загроз життю громадян, завадити доступності державних послуг і створити фінансовоекономічні проблеми загальнонаціонального рівня.

За таких умов розвитку міжнародного та внутрішнього безпекового середовища, стану підготовленості і оснащеності Збройних Сил України та інших складових сил оборони є важливим всеосяжне дослідження основних тенденцій, які проявляються у сучасних війнах та збройних конфліктах, ролі у них військового чинника, пріоритетних напрямках розвитку збройних сил інших країн світу, форм і способів їх застосування. Таке дослідження $\epsilon$ невід'ємною умовою забезпечення ефективної реалізації політики професійної військової підготовки майбутніх офіцерів щодо захисту державного суверенітету та відновлення територіальної цілісності держави.

Сучасна воєнна наука базується на основі аналізу бойових дій збройних сил США, РФ, Ізраїлюта Арабських країнвпродовж останніх 40 - 50 років, починаючи з війни в Афганістані (1979 - 1989 роки), війни у Перський Затоці(1990 - 1991 роки) та на сьогодні з продовженням збройних конфліктів у Сирії та Лівії.

Серед основних ріс сучасної війни високої інтенсивності визначаються таки:

зростання просторового розмаху одночасного ведення воєнних дій на різних напрямках або районах, тобто весь театр воєнних дій стає місцем одночасного ведення бойових дій. Цьому сприяє розвиток засобів дальнього вогневого ураження та високоточної зброї у звичайному оснащенні. Поряд 3 виключно вогневим ураженням, з'являються нові поняття, як електронновогневого ураження із залученням військ радіоелектронної боротьби (РЕБ);

зростання ролі і значення засобів розвідки, спостереження та управління військами (силами). Ці інструменти поєднуються в єдину автоматизовану систему управління та формують єдине інформаційне поле, яке дозволяє випередити противника, від його виявлення до нанесення йому вогневого ураження;

зростання відсотка високоточних засобів ураження різних типів під час ведення бойових дій, при цьому здійснюється перенесення наголосу 3 авіаційних ударів на удари крилатими ракетами та безпілотними літальними апаратами;

збільшення засобів роботизації у сухопутному компоненті під час вирішення окремих бойових завдань [6, с.8].

Отже, велике значення у сучасному типі війни має повітряно-космічний вимір, завдяки якому забезпечується інформаційне та вогневе домінування над противником. Головними цілями у сучасному збройному протистоянні $\epsilon$ ключові вузли системи управління, об’єкти економіки, критичної інфраструктури та організації оборони на вищому рівні, а не лише жива сила $\mathrm{i}$ техніка противника.

Окрема увага приділяється початковому етапу війни чи збройного конфлікту, коли здійснюється оперативне та стратегічне розгортання військ (сил), проводяться перші операції. Отже, активні рішучі дії саме в цей період 
мають вирішальне значення. Таким чином на сьогодні інноваційною формою сучасної війни стає швидкоплинна наземна операція після застосування вогневого ураження крилатими ракетами та безпілотними апаратами 3 метою знищення основ для спротиву іншої сторони.

Визначальними чинниками в такій операції буде спроможність дальнього вогневого ураження, безконтактних бойових дій із застосуванням високоточного озброєння, створення єдиного інформаційного поля та завоювання інформаційного домінування над противником. В сучасній війні через відсутність цілісних ліній фронту будуть здійснюватися флангові удари, активні рейдові дії для виходу в тил противнику, створення та підтримки ефекту хаосу [6, с.12].

У багатьох арміях країн світу в сучасних умовах для вирішення різних завдань у локальних війнах та збройних конфліктах створені Сили спеціальних операцій, які розглядаються як потужний асиметричний інструмент ведення війни, який поряд із класичними функціями може залучати до організації на території противника незаконних збройних формувань. Їх завданнями можуть бути рейдові дії в тактичній та оперативній глибині противника, збирання розвідувальних даних, проведення диверсійних та інформаційних заходів тощо. Відсутність цільної лінії фронту створює додаткові можливості для спецпризначенців для проникнення у тил противника та проведення спеціальних операцій серед місцевого населення.Водночас зростає роль десантів різних типів під час проведення широкомасштабної наземної операції.

Відповідно до вимог «Концепції спільних дій: Об'єднані сили і засоби 2020» під час виконання інтегрованих операцій вимагає від військового керівництва Сполучених штатів Америки застосування можливостей швидко та впевнено переміщати Об'єднані військапо всьому світу. Ключове значення для планування й проведення глобальних інтегрованих операції мають вісім компонентів, а саме: використання командування місії; захват, утримання та використання ініціативи; глобальна маневреність; партнерство; демонстрування глибокості в створенні спільних сил; покращення спільної міжзональної взаємодії; використання всіх видів маскування; постійна підтримка багато варіативності для мінімізації непередбачувальних наслідків.

Такі операції залежать від глобальної мережі постачання та транспорту, безпечних комунікацій, інтегрованої та партнерської розвідки, спостереження і здатності рекогносцировки [10].

Під впливом еволюції поглядів на стан міжнародної безпеки, змін у стратегії та тактики ведення війни та засоби і способи забезпечення національної безпеки України зростає розуміння необхідності кардинального переосмислення підходів до комплексної підготовки складовихсил оборони, переконання в тому, що без іiі вдосконалення неможливо добитися головної мети - забезпечитинаціональну безпеку (стабільне міжнародне і внутрішньополітичне положення країни, іi суверенітет i територіальну цілісність, захист і реалізацію національних інтересів) як невоєнними заходами, так й під час застосування воєнної сили. 
Для досягнення цієї мети необхідні розробка і послідовне проведення реалістичного військово-політичного курсу, підвищення рівня соціальноекономічного розвитку, зміцнення сектору безпеки i оборони України, виходячи з військових загроз національним інтересам держави, визначення i використання найбільш ефективних форм i способів підготовки військовослужбовців для підвищення захисту держави.

По-перше, професійна підготовка майбутніх фахівців воєнної сфери повинна мати кінцеву мету, а саме - готовність творчих, адаптованих професіоналів з навиками управління військами (силами) в складних умовах обстановки. Військовослужбовці повинні бути готові до ведення бойових дій в складних умовах у стані постійної небезпеки, потребуючих мужності, витривалості, маневреності, стійкості, а також патріотичності та прихильності цінностям Батьківщини і професійної воєнної етики.

По-друге, це інноваційний розвиток лідерських якостей майбутніх військовослужбовців (рядових, сержантів, офіцерів і генералів), організовуючи поєднання тренувань, знань, розширення досвіду та своїх можливостей. 3 цією метою потрібно поєднувати реальний та віртуальний досвід бойових дій для модулювання складної обстановки та планування операцій в умовах, що швидко змінюються та погіршуються.

По-трете, майбутній військовослужбовець повинен мати таки загальні компетентності, як:вміння розуміти безпекове середовище в якому йому працювати та виконувати свої завдання; правильно оцінювати обстановку та бути готовим до виконання завдань в складних умовах повних несподіванок; розуміти, що обстановка може погіршуватися; працювати у військовому колективі на тлі довіри, відповідних повноважень та в рамках законодавчого поля; приймати рішення на підставі загальних норм етики та цінностей військової служби; критично та стратегічно мислити у питаннях застосування загальних воєнних принципів та концепцій спільних операцій.

По-четверте, молодь росте та виховується в іншому суспільному середовищі - інформаційному, вона використовує технології та інтерактивні соціальні структури для вирішення своїх проблем. Молоді люди - майбутні лідери та вони потрібні військовій службі, тому військовослужбовці повинні бути готові до прийняття певних соціальних і культурних змін.

По-п'яте, потребує уніфікація військової освіти та оптимізація системи органів військового управління, структури, складу і чисельності сил оборони, збалансований розвиток його компонентів.

Виходячи 3 аналізу складових сектору безпеки і оборони України та визначення сил оборони, яке надано у Законі України «Про національну безпеку України» вважається некоректним та включає в себе сили оборони й сили забезпечення оборони та безпеки. До сил оборони напевно необхідно включати лише військові формування (Збройні Сили, Національну гвардію, Службу зовнішньої розвідки, Державну спеціальну службу транспорту), окремі правоохоронні органи зі спеціальним статусом (Державну прикордонну службу) та Державну службу спеціального зв'язку та захисту інформації України. Решта складових (Міністерство оборони, Міністерство внутрішніх 
справ, Державна міграційна служба, Державна служба України з надзвичайних ситуацій, Служба безпеки та Управління державної охорони України, Рада національної безпеки і оборони) віднести до сил безпеки й забезпечення оборони держави [11].

Структура сил оборони України має визначатися пріоритетними функціями та завданнями складових сектору безпеки і оборони, як єдиної функціональної системи забезпечення та безпосередньої участі в оборони, рівнем їх оборонних спроможностей в умовах викликів та загроз у сфері оборони держави та проводитись в єдиної системі навчання.

По-шосте, враховуючи ситуацію, що складається навколо України, потребує удосконалення системи бойової готовності та мобілізаційної підготовки сектору безпеки і оборони держави, підвищення ефективності системи оперативної і бойової підготовки всіх категорій військовослужбовців.

Готовність до дій та оперативне застосування сил оборони передбачатиме визначення найбільш доцільних варіантів способів дій військ (сил) для недопущення просування противника в глибину території, обмеження маневру, виснаження (вимотування) його головних сил, нанесення вогневого ураження резервам, забезпечення проведення контрнаступальних (наступальних) дій на інших напрямках.

Зазначене реалізуватиметься виконанням заходів 3 підготовки території держави до оборони, поєднанням оборонних і наступальних способів дій військ (сил), виконанням заходів територіальної оборони, а також діями сил спеціального призначення щодо організації руху опору на території, яка може бути тимчасово зайнятою противником.

Збройні Сили та інші військові формування України повинні зосередитися на підготовці молодших командирів та здатності їх розвивати спроможності 3 точки зору навиків, методів та підготовки до швидкого реагування на зміни обстановки, приймання доцільного рішення для досягнення мети та ініціативи у бойових діях. Спроможності керування мобільними підрозділами швидко та раптово на загрозливих напрямках [12].

Водночас, необхідно розробити систему мотивації для служби за контрактом. Грошовий зміст контрактника на сьогодні складає $13000-16000$ грн. (400-500 дол.), але цього мало для існування професійної армії. При цьому людина повинна знати, що у нього вирішено питання із службовим житлом та існують перспективи, пов'язані, наприклад, із здобуттям додаткової освіти коштом держави, поїздками в миротворчі місії або навчанням в іноземних коледжах. Він має бути упевнений, що після закінчення терміну контракту буде затребуваний в цивільному житті або ж стане офіцером.

По-сьоме, потребує формування військовослужбовця майбутнього, розвиток воєнної науки та управління персоналом.

Наукова та науково-технічна діяльність має бути спрямована на одержання нових знань щодо закономірностей війн і збройної боротьби, розвитку сил оборони, концептуальних засад запобігання війнам (збройним конфліктам), теоретичних основ будівництва і розвитку сил оборони на основі 
спроможностей, їх застосування, всебічного забезпечення, формування i реалізації воєнно-технічної політики держави.

Важливим $\epsilon$ нарощування спроможностей 3 проведення прикладних наукових досліджень, спрямованих на впровадження результатів наукової роботи на стадіях життєвого циклу озброєння, військової та спеціальної техніки.

Перспективним $є$ проведення дослідно-конструкторських робіт із розроблення та модернізації систем захисту від високоточної зброї, роботизованих систем та озброєння на нових фізичних принципах.

Основним завданням управління людськими ресурсами, персоналом, кадрами $\epsilon$ пошук, ефективне збереження i відтворення, цілеспрямоване формування і раціональне використання професійно підготовлених, відданих людей, які відповідають потребам національної безпеки та оборони України.

По-восьме, подальше удосконалення нормативно-правової бази розвитку сектору безпеки і оборони України, ії правовідносин з цивільним суспільством і державою на демократичних засадах.

Вдосконалення нормативно-правової бази 3 питань підготовки, застосування та планування розвитку сектору безпеки і оборони дасть змогу систематизувати низку нормативно-правових актів (законів, доктрин, концепцій, стратегій, статутів, настанов, дорожніх карт, планів тощо), уточнити повноваження відповідних посадових осіб, вдосконалити взаємодію i координацію дій органів державної влади та силових структур як у мирний час, так і в особливий період, оптимізувати їх структуру та ієрархію.

Висновки та перспективи подальших досліджень. Формування політики професійної військової освіти в сучасних умовах повинна бути націлена на підготовку військовослужбовців, майбутніх командирів на виконання завдань захисту територіальної цілісності України з урахуванням досвіду Операції об'єднаних сил та операцій НАТО. Випускники військових вузів повинні бути підготовлені так, щоб вони могли почати виконання своїх обов'язків в найкоротшій термін після прибуття до військової частини чи підрозділу, спроможні розбиратися в обстановці та приймати доцільні рішення під час організації бойових дій.

3 метою максимального використання позитивного досвіду сучасних міжнародних тенденцій у розвитку військової освіти та воєнної науки i подолання їх негативних наслідків потрібна реалізація низки заходів з розвитку системи освіти протягом життя та активного впровадження у програми вищої військової освіти накопиченого потенціалу збройних сил України та інших країн світу.

Враховуючи швидкі зміни в міжнародному середовищі та безпековій складовій питання формування політики професійної військової освіти у секторі безпеки і оборони України потребує перспектив подальших досліджень. 


\section{ЛІТЕРАТУРА}

1. Зовнішня політика та політика безпеки після оновлення влади: послідовність, зміни, перспективи. // Центр Розумкова, Київ, 2019. С. 38

2. Проблема якості підготовки офіцерів тактичної ланки управління в контексті проведення АТО. А. Зельницький, О. Мітягін, Ю. Приходько // Військова освіта, 1 (31) 2015. C. $-93-102$.

3. Проблемні питання подальшого розвитку системи військової освіти. Телелим В.М., Приходько Ю.І. // Вісник Національного університету оборони України 5 (30) 2012. С. $134-140$.

4. Стратегічні пріоритети підвищення боєздатності Збройних Сил України в контексті професіоналізації військової освіти: політики і процедури. Мітягін О.О., Вітер Д.В. // Центр воєнно-стратегічних досліджень Національного університету оборони України імені Івана Черняховського, Київ - 2020. С. 133 - 137.

5. Інтернет-видання Слово д https://www.slovoidilo.ua/2019/12/13/infografika/polityka/yaki-zbrojni-konflikty-vynykaly-svitipislya-druhoyi-svitovoyi-vijny-ta-choho-vony-pryzvely

6. Сучасний російський спосіб ведення війни: теоретичні основи і практичне наповнення // аналітична доповідь. : Національний інститут стратегічних досліджень, Київ, 2021. C. -29

7. Майбутнє безпекове середовище 2030: Стратегічне передбачення // Міністерство оборони України. : Київ, 2019. С. - 50

8. Ефективний аналіз. Ефективні рішення. RAND Corporation. Інтернет-видання : URL: https://www.rand.org

9. Інтернет-відання : bbc.com : URL : https://www.bbc.com/ukrainian

10. Національна воєнна стратегія Сполучених штатів Америки : URL: http://www.jcs.mil/Portals/36/Documents/Publications/2015_National_Military_Strategy.pdf

11. Про національну безпеку України : Закон України від 21 червня 2018 року №2469-VIII. URL: https://zakon.rada.gov.ua/laws/show/2469-19.

12. Стратегії воєнної безпеки України : Указ Президента України : URL : https://www.kmu.gov.ua/news/uryad-pidtrimav-proekt-strategiyi-voyennoyi-bezpeki-ukrayini.

\section{REFERENCES}

1. Zovnisha politika ta politika bezpeki pislia onovlenia vladu: poslidovnist, zminu, perspektuvu. // Tsentr Rozymkova, 2019, Kyiv. C. 38.

2. Problema yakosti pidgotovki ofitseriv taktuchnoi lanki upravlenia v konteksti provedena ATO. A. Zelnitskii, O. Mitiagin, Y. Prichodko // Viiskova osvita, 1 (31) 2015. C. - 93-102.

3. Problemni putania podalshogo rozvitky sistemu viiskovoi osvitu. Telelum V.M., Pruchodko Y.I. // Visnuk Nazionalnogo yniversitety oboronu Ukrainu 5 (30) 2012. C. 134 - 140.

4. Strategichni prioritetu pidvuchennia boezdatnosti Zbroinux Sul Ukrainu v konteksti profesionalizatsii viiskovoi osvitu: politiku s protsedyru. Mitiagin O.O., Viter D.V. // Tsenter voenno-strategichnux doslidgtn Nazionalnogo yniversitety oboronu Ukrainu imeni Ivana Cheniachovskogo, Kyiv - 2020, C. 133 - 137.

5. Internet-vudannia Slovo I dilo URL: https://www.slovoidilo.ua/2019/12/13/infografika/polityka/yaki-zbrojni-konflikty-vynykaly-svitipislya-druhoyi-svitovoyi-vijny-ta-choho-vony-pryzvely.

6. Sychasnui rosiiskii sposib vedenia viinu: teoritichni osnovu I praktichne napovnennia // analitichna dopovid. : Nazionalnui institute strategichnix doslidgen, Kyiv, 2021. C. - 29.

7. Maibytne bezpekove seredoviche 2030: Strategichne peredbachennia // Ministersvo oboronu Ukrainu: Kyiv, 2019. C. -50.

8. Efektivnii analiz. Efeknivne rishennia. RAND Corporation. Internet-vudannia : URL: https://www.rand.org.

9. Internet-vudannia : bbc.com : URL : https://www.bbc.com/ukrainian. 
10. Natsionalna voennai strategia Spoluchenux shtativ Ameriki : URL: http://www.jcs.mil/Portals/36/Documents/Publications/2015_National_Military_Strategy.pdf.

11. Pro natsionalny bezpeky Ukrainu : Zakon Ukrainu vid 21 chervna 2018 roky №2469VIII.: URL: https://zakon.rada.gov.ua/laws/show/2469-19.

12. Strategia voennoi bezpeki Ukrainu : Ukaz Prezidenta Ukrainu : URL : https://www.kmu.gov.ua/news/uryad-pidtrimav-proekt-strategiyi-voyennoyi-bezpeki-ukrayini.

\section{РЕЗЮМЕ}

\section{Олег Цевелев}

кандидат наук государственного управления главный специалист отдела межведомственной координации управления военной политики Департамента военной политики и стратегического планирования Министерства обороны Украины,

\section{Международное среды безопасности: влияние на формирование политики профессиональной военного образования в Украине}

В статье проанализированы краткое состояние международного безопасности среды на глобальном, региональном уровне и внутренне-политическая обстановка в стране, приведены отдельные новые формы и способы современной вооруженной борьбы. Указанные отдельные вопросы формирования политики профессионального военного образования через призму анализа безопасности среды и изменений, произошедших в войнах современности.

Ключевые слова: среда безопасности, политика профессионального военного образования, вооруженная борьба, военный конфликт, силы обороны, военная подготовка

\section{SUMMARY}

Oleg Tsevelyov

head specialist of the section of interdepartmental coordination department of military policy of the Department of military policy and strategic planning of the Ministry of Defense of Ukraine,

Kyiv, candidate of sciences in public Administration

\section{International security environment: influence on the professional policy military education in Ukraine}

Introduction. The realities of life make objective adjustments or limitations to practical steps, as changes in the international security environment and domestic political living conditions to some extent affect the state's defense capabilities and the preparation of the defense forces to perform their defense tasks. Based on this, it is desirable to maintain a reasonable balance between maintaining the consistency of existing capabilities and development of the country and adjusting the foundations of foreign and domestic policy, a balanced approach to reforming the security and defense sector. With regard to security and defense reform, the role of internal and external factors of an objective and subjective nature, which is rapidly changing and complicated, should be carefully considered.

Purpose. In the article it is analysed the compressed being of international environment of safety in a global, regional level and vnutrishne-politichna situation in a country, separate new forms and methods of the modern armed fight are resulted. Separate questions are outlined in relation to forming of policy of trade military education through the prism of analysis of environment of safety and changes which took place in wars of contemporaneity. 
Methods: the application of general scientific and special legal methods of cognition allowed to solve scientific task to develop a proposal for the policy of professional military education of the constituent forces of the defense modern conditions.

Results: problematic issues of training and joint tasks of the defense forces are investigated by current legislation and, of course, uncertainty the directions of their solution during the defense reform are investigated.

Originality: today conditions, "hybrid" challenges and threats in the field of state defense, the creation of an effective system of professional military education for state defense is possible only on the basis of a clear division and legislative consolidation of generalized functions, tasks and responsibilities of all defense forces.

Conclusion. The formation of a policy of professional military education in modern conditions should be aimed at training servicemen and future commanders to perform the tasks of protecting the territorial integrity of Ukraine, taking into account the experience of Operation Allied Forces and NATO operations. Military graduates should be trained to take up their duties as soon as possible after arriving at a military unit or unit, able to understand the situation and make appropriate decisions during hostilities.

Keywords: environment of safety, policy of trade military education, armed fight, military conflict, forces of defensive, military preparation 